\title{
DAM[N]ED: Mechanizing a Sacred River Landscape Redrawing Territorial Systems in the Narmada River Valley
}

\author{
MARÍA ARQUERO DE ALARCÓN \\ University of Michigan
}

NISHANT MITTAL

University of Michigan

This essay traces the story of the Narmada River and its transformation from a sacred landscape to one of the largest mechanizedterritorialsystemsintheworld. The Narmadatravelssome 1,300 kilometersfrom Amarkantaktothe Arabian Sea; enabling the livelihood of millions, shaping distinct regional identities and embodying a rich cultural imaginary for those worshiping her holy waters. The infrastructural potential of the river was first formulated as a megaregional project in the 1940 s to modernize and bring prosperity to the watershed. Under implementation since the 1980s, the "Narmada Valley Development Project" is incrementally transforming the river intoaninterstateinfrastructuralnetworkofwaterconveyance and energy generation. Through a cartographic and photographic inventory, the project traces the transformation of the natural and cultural systems associated with the Narmada River over time. Pausing at Omkareshwar, a major pilgrimage destination, the essay unfolds the current state of uncertainty andcivic unrest thatthemassive infrastructural worksare placing in the fragile lives of the valley dwellers.

\section{INTRODUCTION}

The Narmada is the fifth longest river in South Asia and the longest west-flowing Indian River, running across the Indian states of Madhya Pradesh, Maharashtra, and Gujarat. The Narmada embodies a rich cultural imaginary, enables the livelihood of millions, and shapes distinct regional identities throughout its 1,300-kilometer course from Amarkantak towards the Arabian Sea. Nurtured by a dense network of tributaries, the Narmada Valley is rich in forested areas of high environmental value. The river traverses highly diverse landscapes from wildlife sanctuaries, to nature reserves and national parks before it forms the delta in the Arabian Sea. Agriculture remains one of the most important activities for Narmada's valley dwellers due to its abundant fertile land. Although many of these features have been heavily impacted in recent years by the accumulation of infrastructural works in and along the river bed, the Narmada waters continue to sponsor diverse wildlife and agricultural production. This infrastructure's dense network of electric lines and canals has redrawn the Narmada River watershed, enabling it to provide irrigation to endless agricultural fields as well as power homes and emerging industries thousands of kilometers away from the riverbed.

\author{
DHARA MITTAL \\ University of Michigan
}

OLAIA CHIVITE AMIGO

University of Michigan

The river continues to attract development and activities from preserving contained historic cities to promoting disorderly and fast growing new uses. Jabalpur is the largest city in close proximity to the river, and at a distance Bhopal, Indore, and Vadodara hold influence within the watershed. As with nature reserves and agricultural production, the incremental implementation of infrastructure triggers new urban types and identities. As former valleys are inundated and renamed as reservoirs, urbanization along the Narmada River's remade shore-lands takes the shape of touristic resorts, recreational areas, and power plants. Each district sponsors varying ideals of prosperity while coping with the loss of smaller villages and temples, and the legacy of forced displacement.

Yet, the Narmada River is a living body, and her holy waters sponsor a unique landscape that resists domestication. The Narmada River is considered a sacred river in the Indian mythological imaginary. Therefore, she welcomes millions every year as part of the Parikrama, a 2,600-kilometer holy pilgrimage circumambulating the river. A dense network of temples, kunds, ashrams, ghats, and the river herself, mark the rich mythological landscapes that house a multitude of celebrations and rituals throughout the year. The Narmada embodies the certainty of the everyday landscape, where an ephemeral choreography of activities reclaims the shorelands from dawn to dusk. It also hosts the landscape of the intangible and symbolic, hiding and revealing innumerable memories and meanings.

Through a series of cartographic studies and photographic inventories, this essay traces the contrasting narratives of modernization and massive public works as well as those of physical and spiritual, all belonging to the intangible Narmada river landscapes. The journey pauses in Omkareshwar, an important destination in the Narmada Parikrama where pilgrims visit its many temples and encounter the Narmada holy waters at the ghats in the Sangam. As pilgrims engage in bathing rituals with the decreasing water levels, the daunting presence of the Omkareshwar Dam hides behind a large reservoir that submerged many villages and sacred sites in its making. This sacred site is located halfway through the river's course, and it embodies the conflict that exists between 


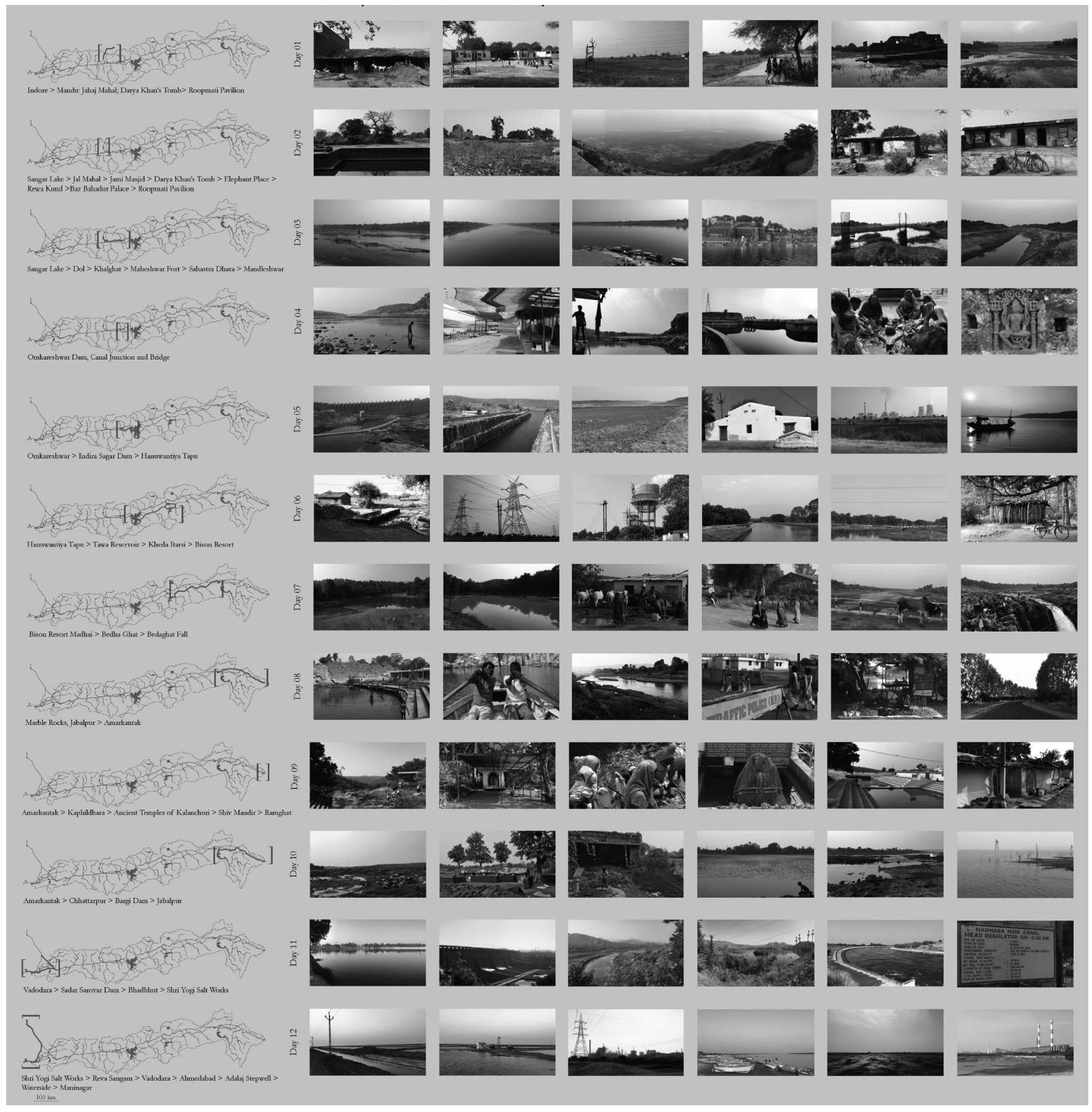

Figure 1. The field trip along the Narmada River Valley took place during November 2017. The first part of the trip started in Indore and took us to the birth of the river, in Amarkantak, and then back to Jabalpur. The second part started in Vadodara towards the Narmada River Delta and back to Ahmedabad.

imposed notions of prosperity and the local resistance that protects the certain, intangible values of the Narmada.

\section{DA[M]NED}

The topographic diversity of the Narmada River watershed and the boundless productive landscapes it traverses captured the imagination of the national government in the late 1940s. At the time, the infrastructural potential of the
Narmada River was first considered as a potential driver of modernization for the rural villages and urban centers along the watershed. The Narmada Valley Development Project (NVDP) was finally conceptualized in the 1960s and incrementally implemented since the 1980s to harness the untapped hydrological resources of the river. The project comprises a network of infrastructural interventions that includes 30 large dams, 135 medium dams, 3,000 small dams, and thousands 

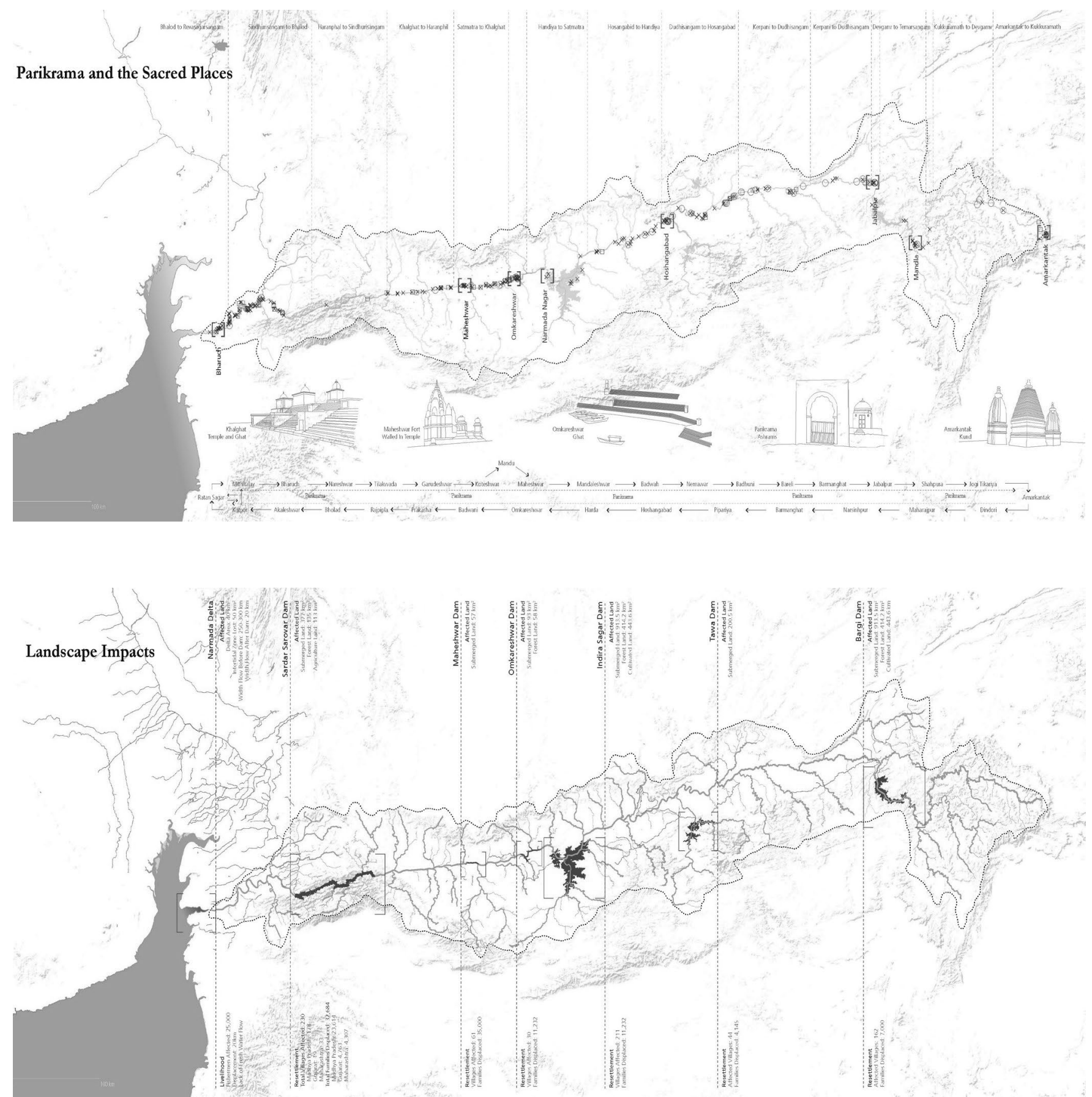

Figure 2. Series of watershed cartographies portraying the most important religious destinations in the parikrama and the largest infrastructural projects incomponents along the Narmada River.

of kilometers of canals. Operating at capacity, it aims to provide potable water to almost 40 million people, irrigation for some six million hectares of land, and hydroelectric power for the entire region. The largest, and one of the more contested amongst these components, is the Sardar Sarovar Project. Located among the states of Madhya Pradesh, Maharashtra, and Gujarat, Sardar Sarovar is a multipurpose infrastructure that provides additional irrigating capacity, drinking water, industry water supply, and 1,450 megawatts of hydro power to Gujarat and Rajasthan. ${ }^{1}$ The dam is 138.68 meters high with a total reservoir capacity of $377 \mathrm{~km}^{2}$. The dam enables irrigation of distant command areas in Gujarat and Rajasthan through the $460 \mathrm{~km}$ long Narmada Main Canal along with thousands of kilometers of subsidiary canals. The Narmada Control Authority (NCA), an interstate administrative body, leads the project's implementation and monitors 


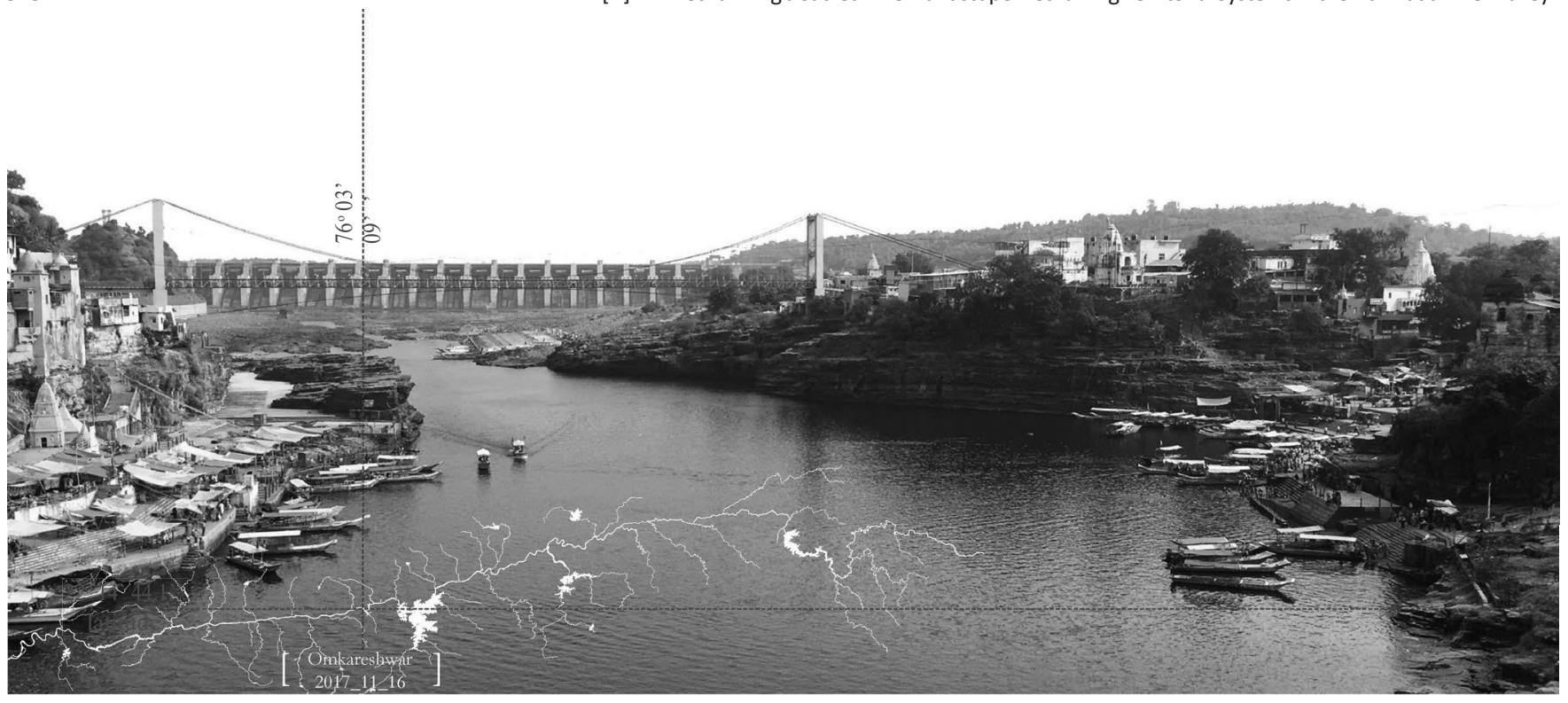

Figure 3. View of Omkareshwar from the bridge, with the massive dam vigilant, defying the modest presence of the temples and the ghats.

environmental and rehabilitation compliance. ${ }^{2}$ The Narmada Water Disputes Tribunal (NWDT) was constituted in 1969 to manage inter-state disputes on the benefits of water and energy shares.

Other project components with large footprints in the Narmada River valley are the Omkareshwar, Indira Sagar, Tawa, and Bargi Reservoirs, representing a total submerged area of roughly $1,500 \mathrm{~km}^{2}$. To make room for the ever-expanding dams, reservoirs, electric power transmission lines, and canals, the government has displaced thousands of families, altering their livelihoods forever, without always just compensation. The sacred waters of the river have transformed into an interstate infrastructural network of water conveyance and energy generation over the course of 30 years; despite local resistance and pressures (that arose before construction) to assess the project's real environmental and social impacts.

The NVDP's scale and its ruthless implementation strategy have been widely questioned, sparking heated national debates favoring more stringent socio-environmental protection measures to seize the impact of such mega-development projects. ${ }^{3}$ Over the years, reports alerting about the lack of proper mitigation on the NVDP impacts abound. In the case of some of the largest dams, the calls transcended local spheres and triggered international scrutiny by different lending organizations. This situation is well illustrated by the World Bank's unprecedented withdrawal from the Sardar Sarovar project in 1994, responding to social and environmental concerns. However, despite pressure from international organizations and local civil society, the Indian Government reinstated its power by moving forward with the project. After governmental approval for raising the height of the dam in 2014, some additional 245 villages in the valley were threatened by submersion. ${ }^{4,5}$ In 2015 , over 250,000 displaced people had yet to be resettled. The national government has found a way to finance and implement the Sardar Sarovar project incrementally, regardless of opposition; despite cases against its environmental and social impacts that remain the center of litigation at every court level. Projected to be completed by 2021, this infrastructural component is just one of the many projects tied to the NVDP that has been highly contested by environmentalists, academics, activists, local agencies, and residents. Amongst these groups is the Narmada Bachao Andolan, a coalition of local people's movements in Madhya Pradesh, Maharashtra, and Gujarat, whom have fought for the rights of the native people along the river for the last 30 years. The coalition has brought attention to the project's innumerable environmental and social justice issues related to displacement; as well as the impacts of centralized water management decisions on the most vulnerable local populations. Their current focus targets the resettlement and rehabilitation processes. They are fighting for the rights of the most vulnerable families that are being evicted from their homes and agricultural fields, and not always being offered just compensation.

OMKARESHWAR AND THE TEMPLES OF MODERN INDIA At the confluence of Narmada's sacred and mechanized landscapes stands Omkareshwar; a millennial-long revered pious territory embodying the impacts that accompany a dramatic transformation to a landscape of extraction. The historic city conflates the struggle to mediate two disparate conceptions of the world, with the Narmada River and its political instrumentalization at the center. The Omkareshwar dam, built 2003-2007, represents the national agenda of progress and prosperity-- domesticating water and generating energy. The ancient temples, the ghats, and the many religious symbols 


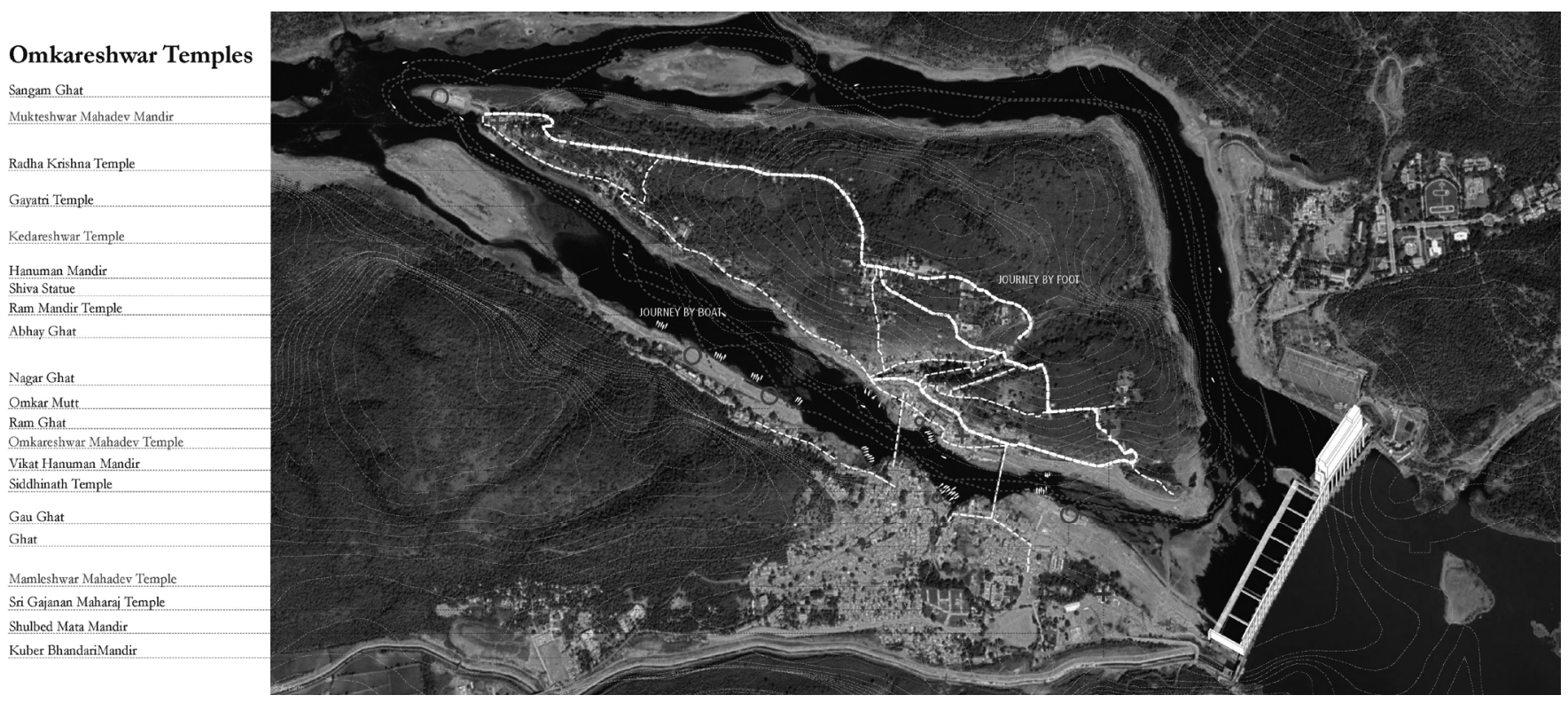

Figure 4. Aerial view highlighting the location of the temples and the parikrama route at Omkareshwar

punctuate the sacred landscape in front of the dam beyond, ringing ephemeral bell sounds and worship songs throughout the historic city. Omkareshwar is an important destination in the Narmada Parikrama. Pilgrims visit the many temples that are situated throughout the hilly topography of the city, and encounter the Narmada holy waters within the many ghats and at the Sangam, the sacred river's confluence. As pilgrims engage in bathing rituals with decreasing water levels, the daunting presence of the Omkareshwar Dam hides behind a large reservoir that submerged many villages and sacred sites in its making.

In Hinduism, the geophysical characteristics of a site make it sacred. The city of Omkareshwar is located at the navel of the Narmada River, halfway between its source and the estuary, flanked by the Vindhya and Satpura Ranges. The city has a population of $10,063^{6}$ and expands over the two banks steep slopes that rise 150 meters above the river. Three distinct settlements form the city. Shivapuri lies at the northern bank and houses the Omkareshwar Temple. Brahmapuri and Vishnupri are located at the southern bank, all separated by a narrow valley where the Kapila stream flows. The northern and southern city edges facing the river have distinctly vary- ing spatial characters. The topography in the north allows for the manifestation of a clear edge through retaining walls, ghat plinths, and building facades, whereas the steep south- ern edge restricts development to the upper planes leaving the natural terrain visible.

The topography, waterways, and established sacred institutions have played a major role in the city's spatial organization and patterns of development. This spatial organization is considered holy in accordance with the ancient science of architecture called the Vastu Purusha Mandala. ${ }^{8}$ The positioning of the Omkareshwar, Brahma, Vishnu, and Amreshwar Temples give sacred order to the landscape while a dense carpet of residential and commercial uses inhabit the sides along a steep network of streets connecting the sacred sites and the Narmada waters. A succession of little shops, places to eat, lodging houses, and dharamshalas-charitable rest houses for travelers-occupy these streets along the pilgrimage route. The kinetic landscapes of changing rhythms and lights, sounds and voices, colors and smells, welcome the pilgrim within the static geographic frame.

At Omkareshwar, the Narmada branches into the Kaveri and meets it again at the western point of the island called "Sangam." This river bifurcation forms the Mandhata Island, a triangular plateau that lends these grounds a deep spiritual dimension. Omkareshwar is home to one of the Hindu God Shiva's twelve transcendent lingas, and venerated as the physical manifestation of OM, a sacred spiritual symbol in Hinduism. The southern part of the city has a steep slope sheared by a deep narrow valley called the "Go Mukh," or cow's mouth, from where a brook called Kapila runs. These natural features, along with their symbolic meaning, render the landscape sacred. ${ }^{9}$ They attract an average of 4,500 pilgrims daily, with visitors increasing to 150,000 to 200,000 during festivals. During Kartik Purnima, a 10 -day festival, as many as 500,000 pilgrims visit Omkareshwar. ${ }^{7}$

The Omkareshwar Parikrama is a major ritual associated with the Mandhata Island, and it is part of the Narmada Parikrama, an important Hindu ritual that symbolizes travel around the universe. The $16 \mathrm{~km}$-long circumambulatory path begins at the Omkareshwar Jyotirlinga Temple, the sacred representation of Shiva, and includes many temples and sacred places 
situated along the route. The Kherapati Hanuman, Omkarnath Ashram, Ram Krishna Mission Ashram, Gayari Mandir, and Rinmukteshwar Temples lie in the first stretch, from the beginning of the path to the Sangam. The huts of many Sadhus (holy persons in Hinduism), together with the temples, populate the areas in proximity to the ridge. The Parikrama continues towards the east with the Gauri Somnath and Siddharnath Temples, and ends when the pilgrim returns to the Omkareshwar Jyotirlinga. Many rituals punctuate the shore-lands of the Narmada at Omkareshwar together with the physical presence of the temples; attracting pilgrims and other visitors alike. One such ancient tradition links the Narmada and the Shivalinga, an abstract representation of Hindu deity Shiva. Every Monday, the Shivalinga from Omkareshwar Temple travels on a palanquin to the water's edge on the Kotitirtha Ghat, and is placed on a boat. The boat takes rounds in the river and returns to the Gaumukhi Ghat before returning to the temple through the market procession. Songs, dance, music, and vibrant colors accompany the ritual.

The Narmada waters, the site topography, and their sacred associations influenced Omkareshwar's emergence and historic development patterns. However, the city and its surrounding landscape's recent transformation emerged from a different imperative. Famously termed by Nehru as the temples of modern India, the Omkareshwar Project embodies that ideal of progress. The dam sits in close proximity to the city, dominating the valley, representing the massive public works program, and advancing the progressive mechanization of the Narmada River. The numbers are impressive: the multipurpose project consists of a 949 meter-long concrete dam with a height of 73 meters, a gated spillway to irrigate 283,324 hectares, and it has the capacity to generate hydropower of $520 \mathrm{MW} .{ }^{10}$ The irreversible valley transformation resulting from the inundation has impacted natural areas, farmland, and rural villages alike. The initial stages of implementation are rift with miscalculations and underestimates related to people affected and final submergence levels. ${ }^{4}$ Without an Environmental Impact Assessment and an updated cost/ benefit analysis, the project received clearance to submerge between 2,471 and 5,829 hectares of natural forestland that was habitat for large mammals like nilgai, spotted deer, leopards, tigers, sloth bears, wild boars and 130 species of birds. ${ }^{11}$ To make room for the reservoir, the Omkareshwar project displaced 30 villages, with estimates of 4,319 project affected families (PAFs) needing relocation. According to NHDC, eleven resettlement sites had been developed and over a third of the PAFs had been resettled by July 2006 .

\section{THE MAKING OF A NEW LANDSCAPE: GLOBAL} FINANCE AND LOCAL CONTESTATION

This landscape modification situates the town of Omkareshwar on the confluence of two bipolar associations with the river. At one end, it is a major destination of the parikrama marking the river's sacredness. At the other, it is a territory marked by large scale infrastructures of extraction that render the commodification of water explicit. Mechanized systems now control the flow of the river and regulate the sacred rituals along and across the river. While these two functions of spirituality and commodification battle for their distinct presence in the landscape, their very coexistence depends on the waters of the Narmada River flowing through. The 2017 drought in the region rendered visible this fragile balance. To maintain reservoir volumes as required by the infrastructural needs for energy production upstream, the river was almost erased downstream. As a result, the pilgrims at Omkareshwar were forced to turn the water parikrama into a walking route.

RESETTLEMENT + REHABILITATION MADYA PRADESH

House Developed residential plot will be given to the oustee families and their Major sons/unmarried daughter. $502 \mathrm{~m}^{2}\left(60^{\prime} \times 90^{\prime}\right)$ for rural area submerge

$222.95 \mathrm{~m}^{2}\left(40^{\prime} \times 60^{\prime}\right)$ only for urban area submerged Cash Compensation in lieu of house plots Rs.50,000/-

\begin{tabular}{ll} 
Infrastructure & $\begin{array}{l}\text { Drinking water well/tube-well with trough. } \\
\text { Electricity } \\
\text { Link and approach road and drains. }\end{array}$ \\
\hline Facilities & Primary School \\
& Playground/Children's \\
& Park \\
& Panchayat Bhawan-cum-Community Hall \\
& Dispensary \\
& Tree Platform \\
& Pond, wherever feasible \\
& Any other facility such as middle school which was \\
existing in the affected village and its improvement & Place of Worship \\
& $\begin{array}{l}\text { Cremation \& burial } \\
\text { ground }\end{array}$ \\
Seed Store \\
Cactle shed \\
Threshing ground \\
Ear marking of pasture land and its improvement.
\end{tabular}

As one of the largest dams built on the Narmada River, the Omkareshwar dam has been highly contested by grassroot activists and inhabitants of the valley, despite the official narratives of progress that came to justify it. Narmada Bachao Andolan participated in the protests that also attracted the attention of overseas groups. In their long-term struggle to protect the rights of those displaced by the project's 


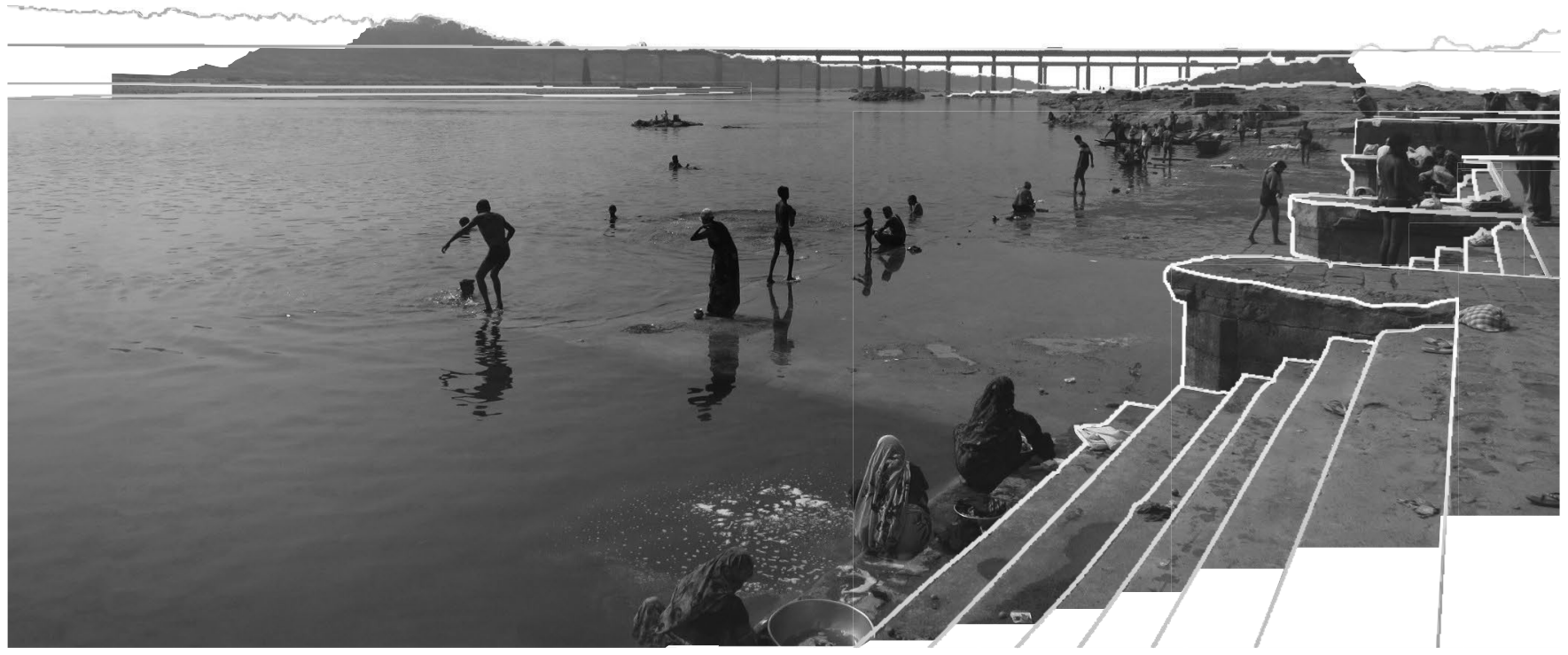

Figure 5. The Narmada river landscapes in transformation.

construction, NBA pointed out deficiencies in the State Government's implementation of its Resettlement and Rehabilitation provisions. They claimed that the Narmada Hydroelectric Development Corporation (NHDC)-the corporation in charge of the works - should not be allowed to raise the reservoir-level until affected villagers were resettled. In 2007, the High Court considered the petition. However, the NHDC and the State government appealed to the Supreme Court of India, and were finally approved to proceed.

Residents in the villages to be submerged reported all kinds of irregularities in the official surveys to address rehabilitation and resettlement (R\&R)-according to a report developed by the Japan Center for Sustainable Environment and Society (JACSES), and the German environment and human rights NGO Urgewald, after their fact-finding mission to the Omkareshwar area in 2004. As previous experience at the Bargi Project in 1987 revealed, these concerns about the irregularities in the surveys of the existing properties were to be taken seriously. In the case of the Bargi reservoir, 111 villages were expected to be flooded, and when the inundation happened, 162 villages and 26 of the designated resettlement areas became under water. The report provides numerous accounts of the government and public authorities' dismissive attitude, as well as various abuses of power when elected village officials tried to access more details. The report also offers evidence of the violations on the R\&R provisions, as the Government of Madhya Pradesh provisions from the 1989 "Rehabilitation Policy for the Oustees of the Narmada Projects" were not followed. Officials never provided the most basic information about the project, the extent of submergence, or the provisions for resettlement and compensation. There were no public consultations in the area, despite these consultations being a requirement by Indian federal law in 1994. Out of the 30 affected villages, not a single family has been offered land-for-land compensation.

Construction of the dam started in November 2003, without an Environmental Impact Assessment and resettlement plan for the project. In Spring 2004, the World Bank's Investment Guarantee Agency, MIGA, turned down an application for the Omkareshwar project because of "environmental and social concerns." In similar terms, Deutsche Bank and ABN Amro refused to finance the Omkareshwar dam, while Barclays Bank admitted "project advising and assisting," but denied the role of bank financing the project. ${ }^{12}$ In June 2004, BankTrack-an international support NGO that tracks banks-had listed the project as one of the 'controversial' works violating the World Bank/IFC guidelines of the Equator Principles. ${ }^{13}$ Another 2004 report outlining the financing of the Omkareshwar dam $^{14}$ offers a glimpse into the transnational interests behind funding infrastructural projects in India. The Narmada Hydroelectric Development Corporation (NHDC), a joint venture of the National Hydro Electric Power Corporation (NHPC, $51 \%$ ) and the state government of Madhya Pradesh (49\%), was responsible for the development of the Omkareshawar project. In July 2003, NHDC signed a US\$360M turnkey contract for construction with a consortium comprising India's hydroengineering Jaiprakash Industries (subcontracting through the German Lahmeyer International and the Portuguese Alstom) and Voith-Siemens Hydro. ${ }^{15}$ In June 2005, NHDC negotiated a debt loan of approximately US\$330M from a consortium of 11 Indian banks, led by Union Bank of India. The equity portion would come jointly from the two NHDC 
shareholders. The irrigation component of the project would be funded by the State Government. The aggregate, officially sanctioned cost of Omkareshwar was about US\$542M.

\section{RIVERS AS LIVING ENTITITIES}

When the India's courts landmark ruling last March 20, 2017, conferred the status of "living entities" to two of her sacred rivers, the Ganges and the Yamuna Rivers ${ }^{16}$, many in the Narmada Valley saw a path to restoration. The ruling had global significance in a time of rising environmental concerns. Giving these rivers legal human rights could change the course of ever-increasing environmental pollution and landscape degradation as justifiable byproducts of progress. The ruling could offer an opportunity to address decades of environmental injustice for those in the Narmada River Watershed who had long battled for the protection of the landscape and the need for more sustainable development practices. However, the ruling decision was appealed by the Uttarakhand's state government" legally unsustainable," and the Supreme Court finally overruled the earlier order in July $2017 .{ }^{17}$

The litigation is taking place at a critical juncture when the national government is invested in advancing other interbasin water transfer public works operating at the national scale. The so-called "Interlinking Project" is predicted to displace millions of people and impact larger ecological river systems despite strong national and international opposition. Given the circumstances, learning from the Narmada River Valley and its transformation can help to better steward more just and sustainable practices of development, bringing prosperity to humans and the environment alike.

Restructuring water landscapes in the interest of prosperity and national identity-building continues to govern contemporary Indian political ideology and has displaced close to 40 million people over the years ${ }^{18}$. The ecological consequences of the drastic transformation of the landscape to serve productive and economic purposes add to the social implications of these massive, politically driven migrations ${ }^{19}$. As India gears up to initiate the implementation of the National River Interlinking Project, termed by several experts as a disaster in waiting, ${ }^{20,21}$ revealing the narratives of struggle and resistance generated by the Narmada Valley Development Project (NVDP) could place design agency as a means for a more resilient and just transformation of the territory. In the process of erasing and redrawing place, livelihoods and identities, the remaking of the sacred river offers an opportunity to formulate possible alternate futures for the region. Our work brings together the conflicting nature of water, energy, human, and spiritual landscapes; visualizing the narratives of resistance, and creating alternate responses to development that call for more just patterns of hinterlands urbanization.

\section{ACKNOWLEDGEMENTS}

This research project is funded through the Research Through Planning, a faculty research grant program at the University of Michigan Taubman College of Architecture.

\section{ENDNOTES}

1. Ruitenbeek, H.J. and C.M. Cartier, Evaluation of Narmada Projects: An Ecological Economics Perspective. Economic and Political Weekly (1995): 2138-2145.

2. Drowning a Valley: Destroying a Civilization. Report of the Central Fact Finding Team's visit to the Sardar Sarovar Project Submergence Areas in Madhya Pradesh and Maharashtra (2015)

3. Amte, B., Narmada project: the case against and an alternative perspective. Economic and Political Weekly (1990): 811-818.

4. Ruitenbeek, H.J. and C.M. Cartier, Evaluation of Narmada Projects: an ecological economics perspective. Economic and Political Weekly (1995): 2138-2145.

5. Project-hit protest rise in Sardar Sarovar dam height, in Times of India (2015)

6. Omkareshwar Population Census 2011, accessed on July 2018, at: https:// www.census2011.co.in/data/town/802436-omkareshwar-madhyapradesh.html

7. Deven, Gajjar. A study of the spatial structure of a temple town Omkareshwar, Madhya Pradesh. Ahmedabad : CEPT University Thesis (2014)

8. Fazeli $\mathrm{H}$ and $\mathrm{A}$ Goodarzi, The principles of vastu as a traditional architectural belief system from an environmental perspective. WIT transactions on https://www.witpress.com/Secure/elibrary/papers/ARC10/ARC10009FU1.pdf

9. Cremin, Emilie. "Omkareshvara, A Holy City of the Narmada in the Course of Transformation." (2005)

10. Omkareshwar Major Irrigation Project. Accessed on July 2018, at: http://www.india-wris.nrsc.gov.in/wrpinfo/index php?title=Omkareshwar_Major_Irrigation_Project_JI00929

11. JACSES/ Urgewald. The Omkareshwar Dam in India: Closing Doors on Peoples' Futures. Report available at the Japan Center for a Sustainable Environment and Society (2004). Accessed on July 2018, at: www.jaces.org/sdap/omkare/ Omkareshwar-Briefing.pdf

12. Barclays accused over Indian dam (2004). Accessed on July 2008, at: https:// www.theguardian.com/money/2004/oct/02/accounts.business

13. The Equator Principles: On 4 June 2003, a group of ten international banks adopted the 'Equator Principles' of project financing, a set of guidelines relating to ecological and social risks in a project drawn up by the World Bank and its private-funding arm, IFC. Under these, all projects of above US\$50M were to be categorized as A, B, or C, depending on whether such risks were high, middle, or low. All A and B category projects would need to gain an EIA prior to being considered for funding by the Equator banks (www.equatorprinciples.com)

14. Willem van Gelder, Jan. The financing of the Omkareshwar dam in India: A research paper prepared for Friends of the Earth England Wales and Northern Ireland (2005). Accessed on July 2008, at: https://www.banktrack.org/ manage/ems_files/download/the financing_of_the_omkareshwar_dam_

15. Green light for Omkareshwar, International Water Power and Dam Construction (2007). Accessed in July 2018 at: http://www.waterpowermagazine.com/features/featuregreen-light-for-omkareshwar/

16. "Ganges and Yamuna rivers granted same legal rights as human beings" The Guardian online (2017). Accessed on July 2018, at: https://www.theguardian.com/world/2017/mar/21/ ganges-and-yamuna-rivers-granted-same-legal-rights-as-human-beings

17. "India's Ganges and Yamuna rivers are 'not living entities'" BBC online (2017). Accessed on July 2018, at: https://www.bbc.com/news/ world-asia-india-40537701

18. Roy, A., The greater common good (1999).

19. Singh, R., River linking spells ecological disaster for India, in The Times of India, J. Deogharia, Editor. (Times of India: India. 2016)

20. Malhotra, S., The River Linking project is a recipe for disaster: Vandana Shiva, in Business Today. India (2014).

21. Patkar, M., River Linking: A Millenium Folly? National Alliance of People's Movements (2004) 